\title{
Exploring nurse perceptions and experiences of resilience: a meta-synthesis study
}

Eun Young Kim

Korea University

Sung Ok Chang ( $\square$ sungok@korea.ac.kr)

Korea University

\section{Research Article}

Keywords: Resilience, Nurses, Perception, Experiences, Qualitative Review

Posted Date: September 28th, 2021

DOI: https://doi.org/10.21203/rs.3.rs-929372/v1

License: () (7) This work is licensed under a Creative Commons Attribution 4.0 International License. Read Full License

Version of Record: A version of this preprint was published at BMC Nursing on January 19th, 2022. See the published version at https://doi.org/10.1186/s12912-021-00803-z. 


\section{Abstract}

Aim To understand nurse resilience in depth by integrating the qualitative research results on nurses' resilience-related experiences.

Methods : We applied the seven steps of the meta-ethnographic process by Noblit and Hare (1988). Six databases (PubMed, CINAHL, EMBASE, Web of Science, Cochrane, and Google Scholar) were used to search for studies published from January 2011 to August 2021.

Results Sixteen qualitative studies were included. The four themes of "self-development though focusing on one's inner self", "building a positive strength for life", "developing one's own strategy for overcoming diversity" and "forward thinking to become a better nurse by planning for the future" illustrate that they want to promote their inner strength and develop themselves through self-examination.

Conclusion : Through this study, we can understand more deeply about the resilience of nurses, and the results can provide basic data for the development of intervention study to improve the resilience of nurses.

\section{Introduction}

Nurses are the largest occupational group in the medical health field. They account for approximately $59 \%$ of the total global medical health workforce [1], and play a very important role in patient care. Globally, in recent years the nursing profession has been a rapidly growing sector of the workforce [2]. However, nurses suffer stress and burnout related to their job, and this has a very negative effect on their mental health [3]. Problems that negatively affect nurses' mental health have serious effects such as reducing nursing professionalism, lowering the quality of care, and increased social financial loss [4].

As nurses' job satisfaction has been declining over recent years, nurses have been found to increasingly be highly likely to have negative perceptions about their job [2]. Nurse job satisfaction is related to the turnover rate, which affects the quality of patient nursing care. As concern over nurse job satisfaction and burnout is increasing worldwide [5], timely studies of concepts that can ameliorate the negative job perceptions caused by the negative experiences of nurses are required.

Resilience is a positive concept that allows nurses to overcome stressful situations [6] and to adapt positively, resulting in psychological well-being and the maintenance of mental health [7, 8]. In a recent previous study, nurse resilience was found to significantly reduced nurse burnout [9, 10]. Resilience is emerging as an important concept for reducing the psychological burden of nurses and increasing their physical and mental health, since resilience has been shown to have a mediating effect on the relationship between burn out and physical/mental health [11].

\section{Background}

Most people have life-threatening experiences or are exposed to one or more stressors in their lifetime [12]. Therefore, it is very important to improve and adapt mental health to recover from the adversities one faces and to adapt positively. Since nurses in particular are exposed to wide-ranging stresses, the positive ability to overcome such adversities can play a very important role for them. The concept of resilience originated in psychology $[13,14]$ and can be described as an individual's characteristics, processes, and outcomes [15]. Research into nursing resilience has been steadily improving, and over the last 10 years the importance of the concept of resilience has become emphasized as the related research has rapidly increased. In particular, resilience has been proposed as a solution to burn out $[9,10,16]$ and mental health issues $[17,18]$, which nurses frequently suffer from, and related research has been actively conducted.

Nurse resilience is a complex and dynamic process that changes over time and according to the situation, embodying not only personal attributes but also external resources, and describes a nurse's ability to adapt positively to stress and adversity [19].

Academic interest in nurse resilience has been increasing recently, and many qualitative studies are being conducted to explore the essence of nurse resilience. However, there has been a practical limit to understanding the concept of nurse resilience through previous studies due to the diversity of the qualitative studies and the differences in their findings on the essence of nurse resilience.

Qualitative meta-synthesis is a methodology for synthesizing and analyzing individual qualitative research [20]. This methodology is recognized as a useful tool for analyzing the meaning, experience, and perspective of participants' expressions [20]. It is a methodology for accumulating knowledge and deriving expanded knowledge and new interpretations from the results of the areas of research and phenomena suggested by existing studies [21]. It is also a research methodology that enables more specific suggestions for future studies [20].

Noblit and Hare developed another meta-synthesis method, meta-ethnography in 1988 [22]. This method has the potential to lower study duplication, create new research questions, and promote higher-level analyses [23].

In this study, the results of qualitative studies on nurse resilience are integrated, a new interpretation is attempted and aspects of resilience phenomena are comprehensively elucidated. This study will help provide basic information for the research and development of interventions to improve nurse resilience. The purpose of this study was to systematically review and synthesize the qualitative evidence on nurse resilience experience.

\section{Aim}

The aim of this study is to understand nurse resilience in depth and to suggest directions for future research through the process of synthesizing and integrating qualitative research results on nurses' resilience-related experiences.

\section{Design}


We used a meta-synthesis methodology, which provides broad understandings of social phenomena, to integrate the findings of qualitative studies [24]. We followed the meta-ethnography method which is suitable for both preserving the interpretations of the primary data and forming new interpretations, theories and models [25]. We applied the seven steps of the meta-ethnographic process by Noblit and Hare [22] : (a) getting started, (b) deciding what is relevant to the initial interest, (c) reading the studies, (d) determining how the studies are related, (e) translating the studies into one another, (f) synthesizing those translations, and $(\mathrm{g})$ expressing the synthesis.

The research question was "How do nurses overcome adversities?", "What are the characteristics of nurses' experiences of resilience?"

This review was prepared in accordance with ENTREQ (Enhancing transparency in reporting the synthesis of qualitative research Statement) guidelines [26]. This meta-synthesis study was registered (CRD42021271541) with PROPERO, which is the International Register of Systematic Reviews.

\section{Search methods}

We used the traditional literature review method. As this method is mainly used for searching literature representing the entirety of the phenomenon of interest, it is suitable for meta-synthesis studies [23].

Literature searches were carried out using six databases (PubMed, CINAHL, EMBASE, Web of Science, Cochrane, and Google Scholar). The search terms used in the search were "Nurses", "Resilience, Psychological", "Qualitative Research", "Hermeneutics" from the Mesh Terms. The search terms were used with the Boolean operators "AND" and "OR" in different combinations. A flow chart of the systematic review of literature selection process of the present research is presented in Fig. 1.

The inclusion criteria required qualitative studies that were: (a) aimed at exploring the resilience of nurses, (b) published from January 2010 to September 2021 (c) peer-reviewed journals (d) published in English, and (e) full-text searchable. The exclusion criteria were (1) nurses' experiences were not reported separately, (2) mixed methods were used but qualitative data could not be extracted or (3) necessary qualitative depth was lacking in the data analysis.

Through the search procedure, 1361 studies were identified. 564 studies were excluded as duplicates, and 699 studies were excluded because they were regarded as not being related to the topic after reading their title and abstracts. 82 studies were excluded after reviewing their full-texts because of a lack of focus on nurses' perspectives, an inappropriate topic, insufficient qualitative criteria, the full text couldn't be found, or the study was over 10 years old. After this process, 16 studies remained for inclusion (Fig. 1).

\section{Quality appraisal}

The Critical Appraisal Skills Programme (CASP) checklist, which contains 10 questions for assessing the reliability and rigor of individual studies, was used to appraise the 16 studies [27]. Two authors independently evaluated the 16 included studies using the CASP checklist. After the appraisal, the two authors compared the CASP results, and any disagreements were resolved through discussion. The degree to which the studies met CASP was evaluated to be $70 \%$ for 4 studies, $80 \%$ for 9 studies, and $90 \%$ for 3 studies. Since all the studies were evaluated as being $70 \%$ or higher, none were excluded from the evaluation process (Table 1). 
Table 1

Summary of the included studies

\begin{tabular}{|c|c|c|c|c|c|c|c|c|c|}
\hline $\begin{array}{l}\text { Article. } \\
\text { No. }\end{array}$ & $\begin{array}{l}\text { Author, } \\
\text { year/Country }\end{array}$ & Research type & Aims & $\begin{array}{l}\text { Sample size } \\
\text { (F:M) }\end{array}$ & $\begin{array}{l}\text { Age of } \\
\text { participants } \\
\text { (in years) }\end{array}$ & $\begin{array}{l}\text { Nursing } \\
\text { experience } \\
\text { (years) }\end{array}$ & $\begin{array}{l}\text { Working } \\
\text { department }\end{array}$ & $\begin{array}{l}\text { Data } \\
\text { collection }\end{array}$ & $\mathrm{Da}$ \\
\hline A1 & $\begin{array}{l}\text { Mealer et al., } \\
\text { 2012/USA }\end{array}$ & Qualitative study & $\begin{array}{l}\text { To identify } \\
\text { mechanisms } \\
\text { employed by } \\
\text { highly resilient } \\
\text { ICU nurses to } \\
\text { develop } \\
\text { preventative } \\
\text { therapies to } \\
\text { obviate the } \\
\text { development of } \\
\text { PTSD in ICU } \\
\text { nurses }\end{array}$ & $27,(27: 0)$ & mean : 46 & $\begin{array}{l}\text { Total: } \\
\text { mean18.5 }\end{array}$ & $\begin{array}{l}\text { Intensive } \\
\text { Care Unit }\end{array}$ & $\begin{array}{l}\text { Semi- } \\
\text { structured } \\
\text { telephone } \\
\text { interviews }\end{array}$ & Th \\
\hline A2 & $\begin{array}{l}\text { Shimoinaba et } \\
\text { al., 2015/Japan }\end{array}$ & Qualitative study & $\begin{array}{l}\text { To explore the } \\
\text { nature of nurses' } \\
\text { resilience and the } \\
\text { way it is } \\
\text { developed }\end{array}$ & $18,(18: 0)$ & $\begin{array}{l}29-53 \\
\text { mean : } 37.8\end{array}$ & $\begin{array}{l}\text { Total :7- } \\
26 \\
\text { In this } \\
\text { department } \\
: 2-8 \\
\text { mean37.8 }\end{array}$ & $\begin{array}{l}\text { Palliative } \\
\text { Care Unit }\end{array}$ & $\begin{array}{l}\text { Face to face } \\
\text { in-depth } \\
\text { interviews }\end{array}$ & $\mathrm{Gr}$ \\
\hline A3 & $\begin{array}{l}\text { Cope et al., } \\
\text { 2016/Australia }\end{array}$ & $\begin{array}{l}\text { Qualitative } \\
\text { portraiture } \\
\text { methodology }\end{array}$ & $\begin{array}{l}\text { To explore } \\
\text { residential aged } \\
\text { care nurses } \\
\text { working in } \\
\text { interim, } \\
\text { rehabilitation and } \\
\text { residential } \\
\text { aged care } \\
\text { perceptions of } \\
\text { resilience }\end{array}$ & $\begin{array}{l}3 \text {,(not } \\
\text { reported), }\end{array}$ & $32-57$ & $\begin{array}{l}\text { Total } \\
\text { :mean28 }\end{array}$ & $\begin{array}{l}\text { An aged } \\
\text { care } \\
\text { environment }\end{array}$ & $\begin{array}{l}\text { Semi- } \\
\text { structured } \\
\text { interviews } \\
\text { painting } \\
\text { with words }\end{array}$ & Th \\
\hline A4 & $\begin{array}{l}\text { Cope et al., } \\
\text { 2016(2) } \\
\text { /Australia }\end{array}$ & $\begin{array}{l}\text { Qualitative } \\
\text { portraiture } \\
\text { methodology }\end{array}$ & $\begin{array}{l}\text { To explore why } \\
\text { nurses chose to } \\
\text { remain in the } \\
\text { Western } \\
\text { Australian } \\
\text { workforce; to } \\
\text { develop insights } \\
\text { into the role of } \\
\text { resilience of } \\
\text { nurses to manage } \\
\text { the context of } \\
\text { nursing work; and, } \\
\text { to identify the key } \\
\text { characteristics of } \\
\text { resilience } \\
\text { displayed by } \\
\text { those nurses }\end{array}$ & $\begin{array}{l}\text { 9,(not } \\
\text { reported) }\end{array}$ & $\begin{array}{l}\text { Not } \\
\text { reported }\end{array}$ & $\begin{array}{l}\text { Not } \\
\text { reported }\end{array}$ & $\begin{array}{l}\text { Interim and } \\
\text { residential } \\
\text { aged care, } \\
\text { academic } \\
\text { setting, } \\
\text { tertiary } \\
\text { acute care } \\
\text { setting }\end{array}$ & $\begin{array}{l}\text { Individual } \\
\text { interviews, } \\
\text { field notes, } \\
\text { memos and } \\
\text { gesture } \\
\text { drawings } \\
\text { interviews }\end{array}$ & $\mathrm{Ph}$ \\
\hline A5 & $\begin{array}{l}\text { Tubbert, } \\
\text { 2016/USA }\end{array}$ & Qualitative study & $\begin{array}{l}\text { To explore the } \\
\text { resiliency } \\
\text { characteristics of } \\
\text { certified } \\
\text { emergency nurses }\end{array}$ & $\begin{array}{l}16 \\
(68.8 \%: 31.2 \%)\end{array}$ & Mean :50 & $\begin{array}{l}\text { Total : } 30 \\
\text { In this } \\
\text { department } \\
: 20\end{array}$ & $\begin{array}{l}\text { Emergency } \\
\text { department }\end{array}$ & $\begin{array}{l}\text { Face to face } \\
\text { interview }\end{array}$ & Co \\
\hline A6 & $\begin{array}{l}\text { Benade et al., } \\
2017 / \text { South } \\
\text { Africa }\end{array}$ & $\begin{array}{l}\text { Explorative } \\
\text { descriptive } \\
\text { qualitative } \\
\text { research }\end{array}$ & $\begin{array}{l}\text { To explore and } \\
\text { describe the } \\
\text { strengths and } \\
\text { coping abilities of } \\
\text { nurses caring for } \\
\text { older persons and } \\
\text { to formulate } \\
\text { recommendations } \\
\text { to strengthen their } \\
\text { resilience }\end{array}$ & $43(43: 0)$ & $\begin{array}{l}\text { Not } \\
\text { reported }\end{array}$ & $\begin{array}{l}\text { Total : not } \\
\text { reported } \\
\text { In this } \\
\text { department } \\
:<6 \text { month } \\
: 2 \\
\text { 1year < } \\
\text { 5years : } 5 \\
\text { 5years < } \\
\text { 10years : } 4 \\
>1 \text { yyears: } \\
27\end{array}$ & $\begin{array}{l}\text { Aged care } \\
\text { department } \\
\text { in an urban } \\
\text { environment }\end{array}$ & $\begin{array}{l}\text { Focus group } \\
\text { interview }\end{array}$ & Co \\
\hline
\end{tabular}




\begin{tabular}{|c|c|c|c|c|c|c|c|c|c|}
\hline $\begin{array}{l}\text { Article. } \\
\text { No. }\end{array}$ & $\begin{array}{l}\text { Author, } \\
\text { year/Country }\end{array}$ & Research type & Aims & $\begin{array}{l}\text { Sample size } \\
\text { (F:M) }\end{array}$ & $\begin{array}{l}\text { Age of } \\
\text { participants } \\
\text { (in years) }\end{array}$ & $\begin{array}{l}\text { Nursing } \\
\text { experience } \\
\text { (years) }\end{array}$ & $\begin{array}{l}\text { Working } \\
\text { department }\end{array}$ & $\begin{array}{l}\text { Data } \\
\text { collection }\end{array}$ & $\mathrm{Da}$ \\
\hline A7 & $\begin{array}{l}\text { Marie et al., } \\
\text { 2017/UK }\end{array}$ & $\begin{array}{l}\text { Interpretive } \\
\text { qualitative design }\end{array}$ & $\begin{array}{l}\text { To observe and } \\
\text { describe the } \\
\text { environment } \\
\text { within community } \\
\text { mental health } \\
\text { workplaces, to } \\
\text { explore the } \\
\text { challenges facing } \\
\text { Palestinian } \\
\text { community } \\
\text { mental health } \\
\text { nurses (CMHNs) } \\
\text { inside and } \\
\text { outside their } \\
\text { workplaces, and } \\
\text { to examine their } \\
\text { sources of } \\
\text { resilience }\end{array}$ & $15(8: 7)$ & $24-60$ & $\begin{array}{l}\text { Not } \\
\text { reported }\end{array}$ & $\begin{array}{l}\text { Mental } \\
\text { health } \\
\text { workplace }\end{array}$ & $\begin{array}{l}\text { Face-to-face } \\
\text { in depth } \\
\text { interviews }\end{array}$ & Th \\
\hline A8 & $\begin{array}{l}\text { Prosser et al., } \\
\text { 2017/Canada }\end{array}$ & $\begin{array}{l}\text { Interpretative } \\
\text { phenomenological } \\
\text { method }\end{array}$ & $\begin{array}{l}\text { To understand } \\
\text { how registered } \\
\text { nurses } \\
\text { in the acute } \\
\text { psychiatric } \\
\text { setting develop } \\
\text { resilience to } \\
\text { sustain his or her } \\
\text { practice. }\end{array}$ & $\begin{array}{l}4 \text { (not } \\
\text { reported) }\end{array}$ & $\begin{array}{l}\text { Not } \\
\text { reported }\end{array}$ & $\begin{array}{l}\text { Total : } 2- \\
21 \\
\text { In this } \\
\text { department } \\
: 2-16\end{array}$ & $\begin{array}{l}\text { Acute } \\
\text { psychiatric } \\
\text { units }\end{array}$ & $\begin{array}{l}\text { Semi- } \\
\text { structured } \\
\text { face-to- face } \\
\text { interview }\end{array}$ & $\begin{array}{l}\text { Int } \\
\text { ph } \\
\text { an }\end{array}$ \\
\hline A9 & $\begin{array}{l}\text { Wahab et al., } \\
\text { 2017/Singapore }\end{array}$ & $\begin{array}{l}\text { descriptive } \\
\text { qualitative design } \\
\text { using Photovoice }\end{array}$ & $\begin{array}{l}\text { To explore the } \\
\text { new graduate } \\
\text { nurses' accounts } \\
\text { of resilience and } \\
\text { the facilitating } \\
\text { and impeding } \\
\text { factors in building } \\
\text { their resilience }\end{array}$ & $9(6: 3)$ & Mean : 24 & $\begin{array}{l}\text { Total: } \\
\text { mean } 1 \\
\\
\text { In this } \\
\text { department } \\
\text { : not } \\
\text { reported }\end{array}$ & $\begin{array}{l}\text { Oncology, } \\
\text { General } \\
\text { Medicine, } \\
\text { General } \\
\text { Surgery, } \\
\text { Psychiatry } \\
\text { and } \\
\text { Paediatric } \\
\text { wards }\end{array}$ & $\begin{array}{l}\text { Focus group } \\
\text { interview, } \\
\text { photographs }\end{array}$ & Co \\
\hline A10 & $\begin{array}{l}\text { Imani et al., } \\
\text { 2018/Iran }\end{array}$ & $\begin{array}{l}\text { Phenomenology } \\
\text { study }\end{array}$ & $\begin{array}{l}\text { To explore Iranian } \\
\text { hospital nurses' } \\
\text { lived experiences } \\
\text { of intelligent } \\
\text { resilience }\end{array}$ & $10(4: 6)$ & $34-52$ & $\begin{array}{l}\text { Total : } 11- \\
28 \\
\text { In this } \\
\text { department } \\
\text { : not } \\
\text { reported }\end{array}$ & $\begin{array}{l}\text { Different } \\
\text { types of } \\
\text { wards }\end{array}$ & $\begin{array}{l}\text { In-depth } \\
\text { interview }\end{array}$ & $\begin{array}{l}\text { Th } \\
(1 ! \\
\text { ap }\end{array}$ \\
\hline A11 & $\begin{array}{l}\text { Jackson et al., } \\
\text { 2018/UK }\end{array}$ & Grounded theory & $\begin{array}{l}\text { To better } \\
\text { understand nurse } \\
\text { burnout and } \\
\text { resilience in } \\
\text { response to } \\
\text { workplace } \\
\text { adversity in } \\
\text { critical care }\end{array}$ & 11(11:0), & $\begin{array}{l}20 s: 5, \\
30 s: 3, \\
40 s: 1 \\
50 s: 2\end{array}$ & $\begin{array}{l}\text { Total :4- } \\
36 \\
\text { In this } \\
\text { department } \\
\text { : not } \\
\text { reported }\end{array}$ & $\begin{array}{l}\text { Intensive } \\
\text { care unit }\end{array}$ & $\begin{array}{l}\text { Open-ended } \\
\text { interviews }\end{array}$ & $\mathrm{Gr}$ \\
\hline A12 & $\begin{array}{l}\text { Ramalisa et al., } \\
2018 / \text { South } \\
\text { Africa }\end{array}$ & $\begin{array}{l}\text { Empirical } \\
\text { qualitative } \\
\text { research }\end{array}$ & $\begin{array}{l}\text { To explore and } \\
\text { describe how to } \\
\text { strengthen the } \\
\text { resilience of } \\
\text { nurses in a work } \\
\text { environment with } \\
\text { involuntary } \\
\text { mental health } \\
\text { care users. }\end{array}$ & $\begin{array}{l}24(\text { not } \\
\text { reported) }\end{array}$ & $\begin{array}{l}\text { Not } \\
\text { reported }\end{array}$ & $\begin{array}{l}\text { Total :2-8 } \\
\text { In this } \\
\text { department } \\
\text { : not } \\
\text { reported }\end{array}$ & $\begin{array}{l}\text { Psychiatric } \\
\text { ward }\end{array}$ & $\begin{array}{l}\text { Open-ended } \\
\text { interview }\end{array}$ & Th \\
\hline A13 & $\begin{array}{l}\text { Ang et al, } \\
\text { 2019/Singapore }\end{array}$ & $\begin{array}{l}\text { Qualitative } \\
\text { grounded theory } \\
\text { design }\end{array}$ & $\begin{array}{l}\text { To generate a } \\
\text { comprehensive } \\
\text { account of the } \\
\text { experiences of } \\
\text { nurses as they } \\
\text { cope with stress } \\
\text { and demands of } \\
\text { work, and to } \\
\text { develop } \\
\text { knowledge of the } \\
\text { phenomenon of } \\
\text { resilience among } \\
\text { nurses. }\end{array}$ & 15(15:3), & $\begin{array}{l}24-68 \\
\text { mean:38 }\end{array}$ & $\begin{array}{l}\text { Not } \\
\text { reported }\end{array}$ & $\begin{array}{l}\text { General } \\
\text { hospital }\end{array}$ & $\begin{array}{l}\text { Individual } \\
\text { interviews }\end{array}$ & $\begin{array}{l}\mathrm{Gla} \\
\mathrm{co} \\
\mathrm{co} \\
\mathrm{m \epsilon}\end{array}$ \\
\hline
\end{tabular}




\begin{tabular}{|c|c|c|c|c|c|c|c|c|c|}
\hline $\begin{array}{l}\text { Article. } \\
\text { No. }\end{array}$ & $\begin{array}{l}\text { Author, } \\
\text { year/Country }\end{array}$ & Research type & Aims & $\begin{array}{l}\text { Sample size } \\
\text { (F:M) }\end{array}$ & $\begin{array}{l}\text { Age of } \\
\text { participants } \\
\text { (in years) }\end{array}$ & $\begin{array}{l}\text { Nursing } \\
\text { experience } \\
\text { (years) }\end{array}$ & $\begin{array}{l}\text { Working } \\
\text { department }\end{array}$ & $\begin{array}{l}\text { Data } \\
\text { collection }\end{array}$ & Da \\
\hline A14 & $\begin{array}{l}\text { Ang et al., } \\
2019(2) / \\
\text { Singapore }\end{array}$ & Photovoice study & $\begin{array}{l}\text { To explore the } \\
\text { meaning of } \\
\text { resilience to } \\
\text { nurses and their } \\
\text { perceived } \\
\text { resilience } \\
\text { enhancing factors }\end{array}$ & $8(7: 1)$ & $27-68$ & $\begin{array}{l}\text { Not } \\
\text { reported }\end{array}$ & $\begin{array}{l}\text { Accident } \\
\text { and } \\
\text { emergency } \\
\text { department }\end{array}$ & $\begin{array}{l}\text { Focus group } \\
\text { interview, } \\
\text { photo }\end{array}$ & Co \\
\hline A15 & $\begin{array}{l}\text { Lin et al, } \\
\text { 2019/Taiwan }\end{array}$ & $\begin{array}{l}\text { Construction- } \\
\text { grounded theory }\end{array}$ & $\begin{array}{l}\text { To explore and } \\
\text { understand the } \\
\text { experiences of } \\
\text { resilience among } \\
\text { nurses in an } \\
\text { overcrowded } \\
\text { emergency } \\
\text { department (ED) }\end{array}$ & 13(13:0) & $23-39$ & $\begin{array}{l}\text { Total : not } \\
\text { reported } \\
\text { In this } \\
\text { department } \\
: 2-17\end{array}$ & $\begin{array}{l}\text { Emergency } \\
\text { department }\end{array}$ & $\begin{array}{l}\text { In-depth } \\
\text { interview }\end{array}$ & $\begin{array}{l}\text { Co } \\
\text { gre }\end{array}$ \\
\hline A16 & $\begin{array}{l}\text { Udod et al, } \\
\text { 2021/Canada }\end{array}$ & Qualitative study & $\begin{array}{l}\text { To investigate the } \\
\text { role stressors, and } \\
\text { how coping } \\
\text { strategies } \\
\text { cultivated nurse } \\
\text { managers' } \\
\text { resilience in rural } \\
\text { workplaces. }\end{array}$ & $16(15: 1)$ & $\begin{array}{l}30 \text { s: } 5 \\
40 s: 9 \\
\text { Over 60:2 }\end{array}$ & $\begin{array}{l}\text { Total : } \\
\text { mean4.6, } \\
10-35 \\
\text { In this } \\
\text { department } \\
\text { : mean } \\
7.28,1-17\end{array}$ & $\begin{array}{l}\text { Rural site in } \\
\text { western } \\
\text { Canada }\end{array}$ & $\begin{array}{l}\text { Individual } \\
\text { semi- } \\
\text { structured } \\
\text { interview }\end{array}$ & Th \\
\hline
\end{tabular}

F:female; M:male; CASP: Critical Appraisal Skills Programme checklist

\section{Data extraction}

Two authors independently reviewed the studies in detail. They each read the studies line by line and tried to derive meaningful concepts by extracting codes. Data extraction for the study was performed using a custom form in Microsoft Excel, including author details, participant characteristics, methods, and original citations [25]. Disagreements between the authors were solved through discussion.

\section{Data synthesis}

Based on the meta-ethnography process [22], the 16 studies were independently read repeatedly by the two authors, data analysis was performed, and then the extracted data were summarized as concepts. In more detail, after organizing the papers in chronological order, the two authors independently read the 16 studies, repeatedly. They then summarized and extracted meaningful concepts and themes. The two authors compared the themes and concepts of the first paper with those of the second paper, and then compared the common themes of those two papers with the third paper to derive concepts and themes. This process was repeated until the last study to synthesize the key concepts and broader themes. To extract the key concepts, the studies were read several times, and the key concepts of each study were listed and analyzed for comparison. The key concepts were formed based on the 'first-order construct' of the study. In the meta-ethnography analysis process, the data is divided into 'first-order construct', 'second-order construct', and 'third-order construct' [28]. The 'first-order construct' is the original study participant's daily language as expressed in their own language in the original study, the 'second-order construct' is the current researcher's interpretation based on the 'first-order construct', and 'third-order construct' is a new interpretation of 'second-order construct' [28, 29]. In this study the authors of the current paper extracted the key concepts of the 'first-order construct', then compared the similarities and differences to form the 'secondorder construct', and finally derived the 'third-order construct' representing the main themes of the study by abstracting the 'second-order construct'. During this process of analysis and synthesis, the two authors continued to discuss their differences of opinion based on their respective academic and clinical backgrounds. The final analysis step, "expressing the synthesis," was accomplished by collating the discussion results. The quotes that best expressed each sub-theme were identified and are presented in the results.

\section{Ethical consideration}

As this study is a review study, as a meta-synthesis, human participants were not included. Therefore, an ethical committee review was not required.

\section{Results}

16 qualitative studies were included in this review study and the publication years were from 2012 to 2021 . A total of 241 nurses participated in the included reviewed studies. Their ages varied widely, from those in their 20 s to those in their 60 s, and they were generally of female gender. Their working departments were varied, and included the ICU, the geriatric ward, the emergency room, the psychiatric ward, and the general ward (Table 1). This study yielded four comprehensive themes of nurse resilience experience. Those are 'self-development by focusing on one's inner true self', 'building a positive strength for life', 'developing one's own strategy for overcoming adversity', 'forward thinking to become a better nurse by planning for the future'. Table 2 shows the key concepts from first-order construct, the second order constructs, and the synthesized themes. 
Table 2

Synthesized themes of nurses' resilience experience

Key concepts from first-order constructs

Self-reflection A2, A3, A4, A5, A8, A11, A13, A14, A16

Focusing on the present $A 2, A 5, A 8, A 9, A 11, A 12, A 13, A 14$

Accept the situation not avoiding A8, A9, A11, A12, A13, A14

Believe in one's ability A2, A5, A6, A9, A10, A12, A13, A14

Expressing their feelings honestly $A 2, A 6, A 10, A 11, A 13$

Recognizing the warning signs of stress $A 5, A 9, A 11, A 13$

Pay attention to physical and emotional demands $A 5, A 6$,

A8, A10, A11, A16

Trying to maintain physical health $A 3, A 4, A 11$

Perceiving self-efficacy A5, A6, A9, A11, A13, A14, A15

Developing various ways of self-care $A 2, A 3, A 4, A 9, A 11, A 13$,

A14, A15

Having self-confidence ${ }^{A 5}, A 6, A 9, A 11, A 13, A 14, A 15$

Trying to control emotions A2, A5, A6, A9, A11, A13, A14, A15

Learning from others' experience and expertise $A 2, A 3, A 4$,

A6, A7, A9, A10, A16

The taking on new challenge $A 2, A 3, A 4, A 5, A 9, A 11, A 13$

Flexible thinking to solve an issue A2, A5, A9, A11, A12, A13,

A14

Preserving and moving forward $\mathrm{A5}, \mathrm{A} 9, \mathrm{~A} 11, \mathrm{~A} 13, \mathrm{~A} 14$

Keeping optimistic attitude in life $\mathrm{A1}, \mathrm{A3}, \mathrm{A4}, \mathrm{A5}, \mathrm{A} 6, \mathrm{~A} 7, \mathrm{~A}$,

A14, A15

Maintaining a sense of humor at work $A 3, A 4, A 6, A 11$

Gratitude for life A3, A4, A6, A7, A12

Living a life of helping others $A 2, A 3, A 4, A 6$, $A 15$

Remembering good experiences from the past $A 1, A 2, A 6$,

A15

Finding joy and pride in what they do A1, A5, A6, A11, A15

Living a regular and healthy life $\mathrm{A} 1, \mathrm{~A} 2, \mathrm{~A} 5, \mathrm{~A} 11$

4. Enjoying their life given to them

Enjoying a variety of leisure activities A1, A2, A5, A11

Creating their own hobbies $\mathrm{A} 1, \mathrm{~A} 2, \mathrm{~A} 5$

Developing their own personal coping behaviors $A 1, A 2$,

A5, A11

Avoiding stress $\mathrm{A} 1, \mathrm{~A} 9, \mathrm{~A} 10, \mathrm{~A} 11$

5. Staying away from stress

Keeping work-life balance A5, A6, A8, A10, A11, A12

Keep distance life from work (Setting boundaries

between home and work) A5, A6, A8, A11, A12

(Second order constructs)

\section{Sub-themes}

1. Recognizing and acknowledging the signs of adversity

2. Striving to grow themselves
Synthesized themes

(Third order constructs)

I. Self-development by focusing on one's inner self
3. Accepting life as positive

囚. Building positive strength for life
囚. Developing their own adversity overcoming strategy 


\begin{tabular}{|c|c|c|}
\hline Key concepts from first-order constructs & $\begin{array}{l}\text { Sub-themes } \\
\text { (Second order constructs) }\end{array}$ & $\begin{array}{l}\text { Synthesized themes } \\
\text { (Third order constructs) }\end{array}$ \\
\hline $\begin{array}{l}\text { Comfort from friendships } A 1, A 3, A 4, A 5, A 7, A 10, A 11, A 12, A 14 \text {, } \\
A 15, A 16\end{array}$ & $\begin{array}{l}\text { 6. Forming one's own defenses through } \\
\text { interactions with human relationships }\end{array}$ & \\
\hline \multicolumn{3}{|l|}{$\begin{array}{l}\text { Getting help from family relationships } A 1, A 3, A 4, A 5, A 7, A 11 \text {, } \\
A 12, A 14, A 15, A 16\end{array}$} \\
\hline \multicolumn{3}{|l|}{$\begin{array}{l}\text { Maintaining good relationship with colleagues } A 1, A 2, A 3 \text {, } \\
A 4, A 5, A 7, A 10, A 11, A 12, A 14, A 15, A 16\end{array}$} \\
\hline \multicolumn{3}{|l|}{ Positive role model $\mathrm{A} 1, \mathrm{~A} 2, \mathrm{~A} 6, \mathrm{~A} 11, \mathrm{~A} 12, \mathrm{~A} 15$} \\
\hline \multicolumn{3}{|l|}{$\begin{array}{l}\text { Sharing their feelings with someone whom they trust } A 1 \text {, } \\
A 2, A 5, A 6, A 11, A 12, A 13, A 14, A 15, A 16\end{array}$} \\
\hline \multicolumn{3}{|l|}{ Get help from experts $A 6, A 9, A 12$} \\
\hline Developing self for the future $A 2, A 3, A 4, A 6, A 7, A 9, A 14, A 16$ & 7. Planning their life for a better future & $\begin{array}{l}\text { Q. Forward thinking to become a better } \\
\text { nurse by planning for the future }\end{array}$ \\
\hline \multicolumn{3}{|l|}{ Preparing for new assignments $A 2, A 3, A 4, A 6, A 7, A 9, A 14, A 16$} \\
\hline \multicolumn{3}{|l|}{ Adaptation to a new situation A2, A7, A9, A14, A16 } \\
\hline \multicolumn{3}{|l|}{ Prioritizing work $\mathrm{A} 5, \mathrm{~A} 8, \mathrm{~A} 13, \mathrm{~A} 14, \mathrm{~A} 15, \mathrm{~A} 16$} \\
\hline $\begin{array}{l}\text { Sense of professional pride } A 2, A 3, A 4, A 6, A 9, A 10, A 11, A 12 \text {, } \\
A 13, A 15, A 16\end{array}$ & $\begin{array}{l}\text { 8. Building self-esteem by thinking about the } \\
\text { value of a job }\end{array}$ & \\
\hline \multicolumn{3}{|l|}{ Value of being a nurse $A 2, A 3, A 4, A 6, A 9, A 11, A 12, A 13, A 15, A 16$} \\
\hline \multicolumn{3}{|l|}{$\begin{array}{l}\text { Satisfaction with career } A 2, A 3, A 4, A 6, A 9, A 11, A 13, A 14, A 15 \text {, } \\
\text { A16 }\end{array}$} \\
\hline \multicolumn{3}{|l|}{ Passion to work $A 2, A 3, A 4, A 6, A 9, A 10, A 11, A 12, A 13, A 15, A 16$} \\
\hline $\begin{array}{l}\text { Developing their knowledge and skills } A 2, A 3, A 4, A 6, A 9, A 12 \text {, } \\
A 13, A 15\end{array}$ & & \\
\hline
\end{tabular}

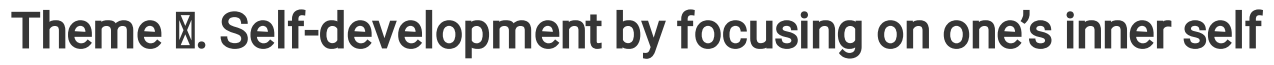

The sub-themes included in theme 1 were "recognizing and acknowledging signs of adversity" and "striving to grow oneself". The nurses tried to find a solution by focusing on the signals of the adversity they encountered, and made an effort to grow through the adversity rather than collapse under it.

\section{Sub-theme 1. Recognizing and acknowledging the signs of adversity}

The nurses did not deny the signs of adversity, but recognized and acknowledged them. The nurses looked inside themselves to find problems and tried to reflect on themselves. They tried to focus on the current situation, and showed an attitude of acceptance to the situation they were in rather than one of avoidance. They believed in their abilities, tried to express their feelings honestly, and tried to recognize the warning signs of stress rather than ignore them. They showed themselves to focus on the state and demands of their bodies and emotions.

"It is difficult.... I feel it is a most difficult thing to reflect on my own feelings. I can understand other people, but I do not understand myself. I think I have experienced a kind of burnout." (A2)

"I thought of ways when something happens so that one can go away, sit down and reflect and then maybe come up with whatever your own strategies are to come back stronger. So if the same thing comes at you again, you know where to run, which direction is faster" (A11)

\section{Sub-theme 2. Striving to grow themselves}

Rather than despair, the nurses wanted to grow on their own. They tried to maintain their physical health and recognized a sense of self-efficacy. In addition, they thought about and developed various ways to take care of themselves. They were confident that they could overcome adversity and tried to control their emotions. Nurses tried not to ignore what others had to say and to learn from their experiences and expertise. They tried new challenges and had various thoughts to solve problems. The nurses showed patience and a willingness to move forward.

"You know more or less that you have to do it and it is going to be tough going. The task could be from manageable to unmanageable depending on what is happening at the moment. I'm able to cope with stress."(A13)

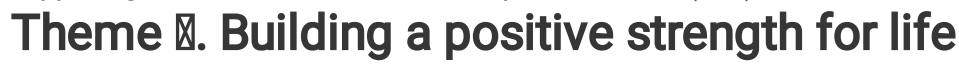


In theme 2, the sub-themes included "accepting life as positive" and "enjoying the life given to them". In this theme, the positive power of nurses is evident. The nurses showed that they were trying to overcome adversity with positivity. A positive attitude toward life and the desire to live the life that was given to them and enjoy life became positive strengths for the nurses.

\section{Sub-theme 3. Accepting life as positive}

The nurses maintained a positive attitude toward life when overcoming life adversities and maintained a sense of humor at work. They were grateful for life and tried to heal themselves by living a life of helping others. They remembered the good memories they had in the past, and drew positive thoughts from them. They found enjoyment and pride in what they do.

"But I try to look at the positive stuff. .. what we are able to do, what changes we were able to make as a result of a catastrophe or just a bad outcome. .. just pull my sleeves up and get in there and get it done and when I can, I do try to encourage communication and good feelings." (A5)

'"'I think every type of nurse has their own type of black humor but I realized a lot of it is a coping mechanism and a way of protection to get yourself through the day" (A11)

\section{Sub-theme 4. Enjoying their life given to them}

Nurses tried to overcome the adversities they faced while enjoying life on their own terms. They tried to live a regular and healthy life, enjoy various leisure activities, and enrich their lives happily while creating their own hobbies. They coped with the situation by developing their own coping behaviors for crisis situations.

"You have to enjoy what you are doing. If you hate your work, it will be a constant stress. I feel that I don't get stressed about it because I feel that no problem is difficult." (A13)

"The joy of working is like a hurdle... like jumping over the hurdle. Each time I jump over a hurdle that I cross, there is always some satisfaction in the job." (A13)

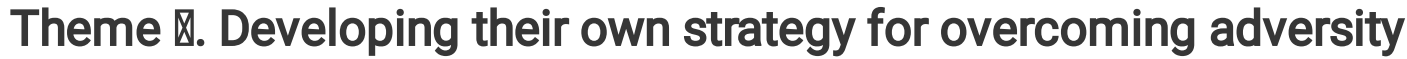

The sub-themes "staying away from stress" and "forming one's own defenses through interactions provided by human relationships" were included in theme 3. Nurses were shown to develop their own strategies when overcoming adversities. They tried to stay away from situations that were stressful to them and formed their own defenses through positive interactions provided by wide-ranging human relationships. These methods of overcoming adversities were their own strategies learned through their own experiences.

\section{Sub-theme 5. Staying away from stress}

Nurses had to face varied sources of stress, but tried to avoid them, such as by trying not to create stressful situations or not focusing on the stress. They tried to maintain a work-life balance so that neither of them became too large or too small, and the work-life balance did not become broken. In addition, by thoroughly separating their work and life, they tried to protect their life thoroughly, avoiding the intrusion of work into their life, and they tried to respect their own privacy.

"Sometimes, I can't control myself. In such situations, I attempt to distance myself from that situation or the immediate environment. In these conditions, I ask my colleagues to continue care delivery and then, I leave the situation. I never stay in such a situation because I know that my presence will aggravate the problem. Thus, I leave that situation and start providing care to another patient."(A10)

"I think that the only way for me to stay resilient is to keep stepping away from the bedside, because that's where all the stress is for me, it's at the bedside. You need to remove yourself from the situation" "I have to have this proper balance and this little routine to maintain a healthy, functional life, and I think the younger ones know that which is good." (A11)

\section{Sub-theme 6. Forming one's own defenses through interactions provided by human relationships}

In their professional positions the nurses developed a variety of interpersonal relationships, including relationships with patients, colleagues, and families. Nurses received comfort from their relationships with friends and comfort and support from their families. The nurses tried to maintain good relationships with their colleagues and other nurses and as colleagues they helped each other in difficult situations. They were also comforted by the developing friendships with their colleagues. In addition, they tried to grow one step at a time by orientating their own future direction through role models and mentors they could imitate. They also received help from a mental health professionals for stress management.

"It's the people you work with. I have a lot of caring friends. I talk to my husband - he always backs me up. I think that how you deal with it.. . with another manager's support. We meet for lunch sometimes - a laughs the best way - we quite often see the funny side." (A4)

"Talking to colleagues because they know the scope of your job. They know what is happening in your ward, so they will be able to understand better.", "I have good friends to whom I can confide my problems. I think it's important you don't bottle up your feelings too much, because you know you can just self-destruct if you're not able to handle it. They may not be able to solve the problem; a listening ear does help." (A13)

"I'm very fortunate as I have a large network of friends and colleagues that I can safely vent to or discuss things with or bounce ideas off that aren't my staff. And I found that you really need that. It is pretty much a lifeline whether you're a front-line manager or if you're a director you need to have that core group of 


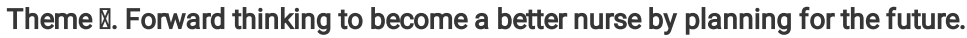

In theme 4, the sub-themes "planning their life for a better future" and "building self-esteem by thinking about the value of a job" were included. The nurses planned their future to live a better life than just leaving their lives to adversity. They felt that they had to develop themselves for a better future, prepare for a new life, and adapt to a new situation. They thought they had to rearrange their work by considering their priorities.

\section{Sub-theme 7. Planning their life for a better future}

In difficult situations, nurses thought about how to live their future. Even in difficult situations, the attitude of planning for the future and thinking about the future rather than staying in the present and despairing was exhibited by nurses. They wanted to develop themselves, to prepare for new assignments including difficult situations, and to adapt well to new situations. They re-prioritized their work and tried to work according to their priorities.

"I always take an experience as an opportunity to learn from it. To grow. I mean, no experience is bad. It may be a bad experience but you can learn from it and try to move on and try to make things better" (A13)

\section{Sub-theme 8. Building self-esteem by thinking about the value of a job}

In difficult situations, nurses tried to gain the strength to overcome the crisis by reminding themselves of themselves as nurses and reflecting on the value of their job. They took pride in their job, thought about the meaning and value of being a nurse, and tried to overcome the crisis while gaining satisfaction from their worthwhile job. They had a passion for their work and wanted to develop their knowledge and skills as nurses and upgrade themselves to the next level through their own development.

"We are the backbone when patients come in. The nurse is the protector of the patient [...] the patient survived because the nurse stuck out her hand and stopped the bleeding. I am proud of her." (A11)

\section{Discussion}

As nurses play a very important role in the medical field, they are exposed to wide-ranging difficulties because of the high intensity of their work. Research on the resilience of nurses, a positive force to overcome this, has recently attracted attention in both research and practice. This study synthesized the result of qualitative research on nurse resilience to explore nurses' experiences of overcoming adversities.

According to the result of this study, when nurses felt that they were going through a difficult situation, they tried to recognize and acknowledge that situation by exploring their inner selves. They focused on themselves and tried to find out exactly what their situation and problems were through self-exploration and not evading the issue. This can be thought of as a preparation process for problem solving. In the context of the more general resilience attributes found by previous studies, it can be noted that the nurse attributes discovered by this study, such as a belief in self-efficacy and a desire to improve oneself, are aspects of resilience in general [30].

However, nurse resilience included wanting to grow on their own while focusing on reality. These results show that nurses in a crisis situation have a strong tendency to rapidly grasp the problem, trust themselves and solve the problem quickly. Also, the nurses showed that they wanted to solve problems and grow step by step rather than staying in crisis. The subjects of this study were incumbent nurses in their 20 s to 60 s, including relatively young subjects, and it likely that the specific active and developmental results derived in this study reflect all of them having the profession of nurse in common.

Nurses tried to overcome adversity by building positive strength in their lives by accepting life positively in crisis situations and enjoying the life given to them. In previous studies, this positivity property as a component of resilience was found to be universal across varied subjects, as part of the concept of general resilience $[29,31]$ and the resilience of chronic disease patients [32]. In addition, nurses showed the characteristics of wanting to live hard and enjoy the life given to them. This can be seen as showing an active attitude to life, and since nurses are generally made up of healthy young people, this showed a different aspect of resilience from those shown by patients who are highly dependent on their families and medical staff [32, 33]. A positive and active attitude towards life could be an important factor to focus on in the development of future intervention research aiming to improve nurses resilience.

Nurses exhibited resilience characteristics for avoiding stress and separating their lives from stress when overcoming adversity. They showed that they were trying to overcome adversity by guaranteeing their own life. This characteristic results from the professional stress of a nurse, reflecting the substantial stress they face from work, and this is something we should pay attention to. Nurses formed their own defense mechanisms through wide-ranging human relationships. The human relationships of nurses were characterized by them wanting to develop their relationships between colleagues to an intimate level, particularly friendship, and them securing comfort from their relationships with such close colleagues. Considering these characteristics of nurse resilience can help create a resilience program that considers the relationships between peers when developing future intervention studies to improve nurse resilience.

As the nurses overcame adversity, they try to adapt themselves by developing themselves and preparing for new situations. They tried to organize their life while arranging work priorities. Nurses tried to overcome adversity by planning for the future and growing one step at a time. In addition, in the face of adversity they had pride as a nurses through reflecting on why they became nurses and reminding themselves of the value of their profession. By raising job satisfaction and the passion for their job, their self-esteem was also raised. They wanted to grow further as nurses by constantly exploring and developing jobrelated knowledge and skills, and they tried to overcome the difficult situations they were in through the process of growth. The characteristic of resilience, that contains the meaning of growth, was revealed in previous studies [34]. However, the resilience of nurses has more specific meanings compared with the previous concept of resilience in that nurses plan for a better future, value the professional meaning of nursing, and want to grow as nurses. The 
characteristics of the resilience of nurses who plan for the future in difficult situations and want to grow one step further can suggest a direction for intervention research to enhance nurse resilience.

Resilience enhancement is an approach that maximizes human inner strength, and we can suggest an intervention that maximizes human inner resource by using mobile with excellent individual accessibility. Mobile health intervention applications have developed rapidly lately and their usefulness is recognized in nursing [35]. Mobile applications can be useful resources for problem solving, providing real-time information and stress reduction strategies for nurses in a variety of healthcare fields and settings. [36]. The present study can suggest basic data and directions for the development of programs to improve nurse resilience.

This study has two strengths. First, the included studies are from very diverse countries, such as the United States, Japan, Australia, South Africa, the United Kingdom, Canada, Singapore, Iran, and Taiwan, reflecting studies of various cultures. Therefore, this study can provide universal knowledge that can be applied worldwide. Second, of the literature used in this study, all 16 articles were found to satisfy the quality evaluation criteria $70 \%$ or more, so the study is based on an analysis of relatively high quality documents of well-organized structure.

Despite these strengths, this study has limitations. The nurses included in the literature were from wide-ranging sub-fields, and the specific characteristics of specialist departments regarding stress were not reflected in the result. Therefore, in the future, conducting qualitative research on the resilience of nurses across nursing sub-fields is suggested. To resolve this, meta-synthesis studies to elucidate the characteristics of nurses within more specific fields can be conducted.

\section{Conclusion}

Emphasizing resilience, a positive force for overcoming adversities, to nurses can play a very significant role in improving the quality of nursing care. When the nurses in this meta study overcame their adversity, they showed the resilience characteristic of wanting to grow a little more by focusing on the inside and trying to find a way to solve the problem on their own. These can be considered as categories of nurse resilience and provide a framework to guide the development of an intervention program for improving nurse resilience. Based on the results of this study, to improve the quality of nursing care we should try to develop varied intervention programs that enhance nurses' inner strength.

\section{Declarations}

\section{Ethics approval and consent to participate}

Not applicable

\section{Consent for publication}

Not applicable

\section{Availability of data and material}

All data generated or analyzed during this study is included in this published article

\section{Competing interests}

No conflicts of interest have been declared by the authors.

\section{Funding}

This study was supported by a National Research Foundation of Korea grant funded by the Korea government (NRF-2021R111A1A01048956).

\section{Authors' contributions}

Conceived and designed the study : EYK, SOC

Performed the data collection : EYK, SOC

Analyzed the data: EYK, SOC

Contributed materials : EYK, SOC

Wrote the first draft of the manuscript : EYK

Prepared figures and tables: EYK

Agree with manuscript results and conclusion : EYK, SOC

\section{Acknowledgements}




\section{References}

1. World Health Organization. State of the World's Nursing Report-2020. 2020. https://www.who.int/publications/i/item/9789240003279/. Accessed 30Aug 2021.

2. Waltz LA, Munoz L, Johnson HW, Rodriguez T. Exploring job satisfaction and workplace engagement in millennial nurses. J Nurs Manag. 2020;28(3):673-81. https://doi.org/10.1111/jonm.12981

3. Khamisa N, Oldenburg B, Peltzer K, llic D. Work related stress, burnout, job satisfaction and general health of nurses. Int J Environ Res Public Health. 2015;12(1):652-66. https://doi.org/10.3390/ijerph120100652

4. Yarbrough S, Martin P, Alfred D, McNeill C. Professional values, job satisfaction, career development, and intent to stay. Nurs Ethics. 2017;24(6):675-85. https://doi.org/10.1177/0969733015623098

5. Lu H, Zhao Y, While A. Job satisfaction among hospital nurses: A literature review. Int J Nurs Stud. 2019;94:21-31. https://doi.org/10.1016/j.ijnurstu.2019.01.011

6. Cusack L, Smith M, Hegney D, Rees CS, Breen LJ, Witt RR, Rogers C, Williams A, Cross W, Cheung K. Exploring environmental factors in nursing workplaces that promote psychological resilience: Constructing a unified theoretical model. Front Psychol. 2016;7:600. https://doi.org/10.3389/fpsyg.2016.00600

7. Foster K, Roche M, Giandinoto J, Furness T. Workplace stressors, psychological well-being, resilience, and caring behaviours of mental health nurses: A descriptive correlational study. Int J Ment Health Nurs. 2020;29(1):56-68. https://doi.org/10.1111/inm.12610

8. Gao T, Ding X, Chai J, Zhang Z, Zhang H, Kong Y, Mei S. The influence of resilience on mental health: The role of general wellbeing. Int J Nurs Pract. 2017;23(3):e12535. https://doi.org/10.1111/ijn.12535

9. Wei H, Roberts P, Strickler J, Corbett RW. Nurse leaders' strategies to foster nurse resilience. J Nurs Manag. 2019;27(4):681-87. https://doi.org/10.1111/jonm.12736

10. Guo Y-F, Luo Y-H, Lam L, Cross W, Plummer V, Zhang J-P. Burnout and its association with resilience in nurses: A cross-sectional study. J Clin Nurs. 2018;27(1-2): 441-9. https://doi.org/10.1111/jocn.13952

11. Arrogante 0 , Aparicio-Zaldivar E. Burnout and health among critical care professionals: The mediational role of resilience. Intensive Crit Care Nurs. 2017;42:110-5. https://doi.org/10.1016/j.iccn.2017.04.010

12. Southwick SM, Bonanno GA, Masten AS, Panter-Brick C, Yehuda R. Resilience definitions, theory, and challenges: Interdisciplinary perspectives. Eur J Psychotraumatol. 2014;5(1):25338. https://doi.org/10.3402/ejpt.v5.25338

13. Fletcher D, Sarkar M. Psychological resilience: A review and critique of definitions, concepts, and theory. Eur Psychol. 2013;18(1):12-23. https://doi.org/10.1027/1016-9040/a000124

14. O'Dougherty-Wright M, Masten AS, Narayan AJ. Resilience processes in development: Four waves of research on positive adaptation in the context of adversity. In: S. Goldstein \& R. B. Brooks. Handbook of Resilience in Children, 2nd ed. Boston, MA: Springer;2013

15. Fletcher D, Sarkar M. Psychological resilience: A review and critique of definitions, concepts, and theory. Eur Psychol. 2013;18(1):12-23. https://doi.org/10.1027/1016-9040/a000124

16. Kelly LA, Gee PM, Butler RJ. Impact of nurse burnout on organizational and position turnover. Nurs Outlook. 2021;69(1):96-102. https://doi.org/10.1016/j.outlook.2020.06.008

17. Foster K, Roche M, Delgado C, Cuzzillo C, Giandinoto J, Furness T. Resilience and mental health nursing: An integrative review of international literature. Int J Ment Health Nurs. 2019;28(1):71-85. https://doi.org/10.1111/inm.12548

18. Mealer M, Jone J, Meek P. Factors Affecting Resilience and Development of Posttraumatic Stress Disorder in Critical Care Nurses. Am J Crit Care. 2017;26(3):184-92. https://doi.org/10.4037/ajcc2017798

19. Cooper AL, Brown JA, Rees CS, Leslie GD. Nurse resilience: A concept analysis. Int J Ment Health Nurs 2020;29(4):553-75. https://doi.org/10.1111/inm.12721

20. Lachal J, Revah-Levy A, Orri M, Moro MR. Metasynthesis: An original method to synthesize qualitative literature in psychiatry. Front psychiatry. 2017;8:269. https://doi.org/10.3389/fpsyt.2017.00269

21. France EF, Wells M, Lang H, Williams B. Why, when and how to update a meta-ethnography qualitative synthesis. Syst Rev. $2016 ; 5: 44$. https://doi.org/10.1186/s1364 3-016-0218-4.

22. Noblit GW, Hare RD. Meta-ethnography: Synthesizing qualitative studies. Sage; 1988

23. Campbell R, Pound P, Morgan M, Daker-White G, Britten N, Pill R, Yardley L, Pope C, Donovan J. Evaluating meta-ethnography: Systematic analysis and synthesis of qualitative research. Health Technol Assess. 2011;15:1-164. doi: 10.3310/hta15430

24. Harwood L, Clark AM. Understanding pre-dialysis modality decision-making: A meta-synthesis of qualitative studies. Int J Nurs Stud. 2013;50:109-20. https://doi.org/10.1016/j.ijnur stu.2012.04.003

25. France EF, Uny I, Ring N, Turley RL, Maxwell M, Duncan EAS., Jepson RG, Roberts RJ, Noyes J. A methodological systematic review of meta-ethnography conduct to articulate the complex analytical phases. BMC Med Res Methodol. 2019;19(1):1-18. https://doi.org/10.1186/s1287 4-019-0670-7

26. Tong A, Flemming K, McInnes E, Oliver S, Craig J. Enhancing transparency in reporting the synthesis of qualitative research: ENTREQ. BMC Med Res Metholdol. 2012;12:181. https://doi.org/10.1186/1471-2288-12-181

27. Critical Appraisal Skills Programme. CASP (Qualitative) checklist. 2018. https://casp-uk.net/wp-content/uploads/2018/01/CASP-Qualitative-Checklist2018.pdf/. Accessed 15 Aug 2021.

Page $12 / 13$ 
28. Cahill M, Robinson K, Pettigrew J, Galvin R, Stanley M. Qualitative synthesis: a guide to conducting a meta-ethnography. British Journal of Occupational Therapy. 2018;81(3):129-37. https://doi.org/10.1177/0308022617745016

29. Toye F, Seers K, Allcock N, Briggs M, Carr E, Barker K. Meta-ethnography 25 years on: challenges and insights for synthesizing a large number of qualitative studies. BMC Med Res Methodol, 2014;14:80. https://doi.org/10.1186/1471-2288-14-80

30. Earvolino-Ramirez M. Resilience: A concept analysis. Nurs Forum. 2007;42(2):73-82. https://doi.org/10.1111/j.1744-6198.2007.00070.x

31. Aburn G, Gott M, Hoare K. What is resilience? An Integrative Review of the empirical literature. J Adv Nurs. 2016;72(5):980-1000. https://doi.org/10.1111/jan.12888

32. Kim EY, LeeY-N, Chang SO. How do patients on hemodialysis perceive and overcome hemodialysis? Concept development of the resilience of patients on hemodialysis. Nephrol Nurs J. 2019;46(5):521-530

33. Rosa F, Bagnasco A, Aleo G, Kendall S, Sasso L. Resilience as a concept for understanding family caregiving of adults with Chronic Obstructive Pulmonary Disease (COPD): an integrative review. Nurs Open. 2016;4(2):61-75. https://doi.org/10.1002/nop2.63

34. Masten AS. Ordinary magic. Resilience process in development. American Psychologist. 2001;56(3):227-38. https://doi.org/10.1037//0003066X.56.3.227

35. Ehrler F, Wu DTY, Ducloux P, Blondon K. A mobile application to support bedside nurse documentation and care: a time and motion study. JAMIA open. 2021;4(3):ooab046. https://doi.org/10.1093/jamiaopen/ooab046

36. Baccin CRA, Dal Sassso GTM, Paixão CA, De Sousa PAF. Mobile Application as a Learning Aid for Nurses and Nursing Students to Identify and Care for Stroke Patients: Pretest and Posttest Results. Comput Inform Nurs. 2020;38(7):358-66. https://doi.org/10.1097/CIN.0000000000000623

\section{Figures}

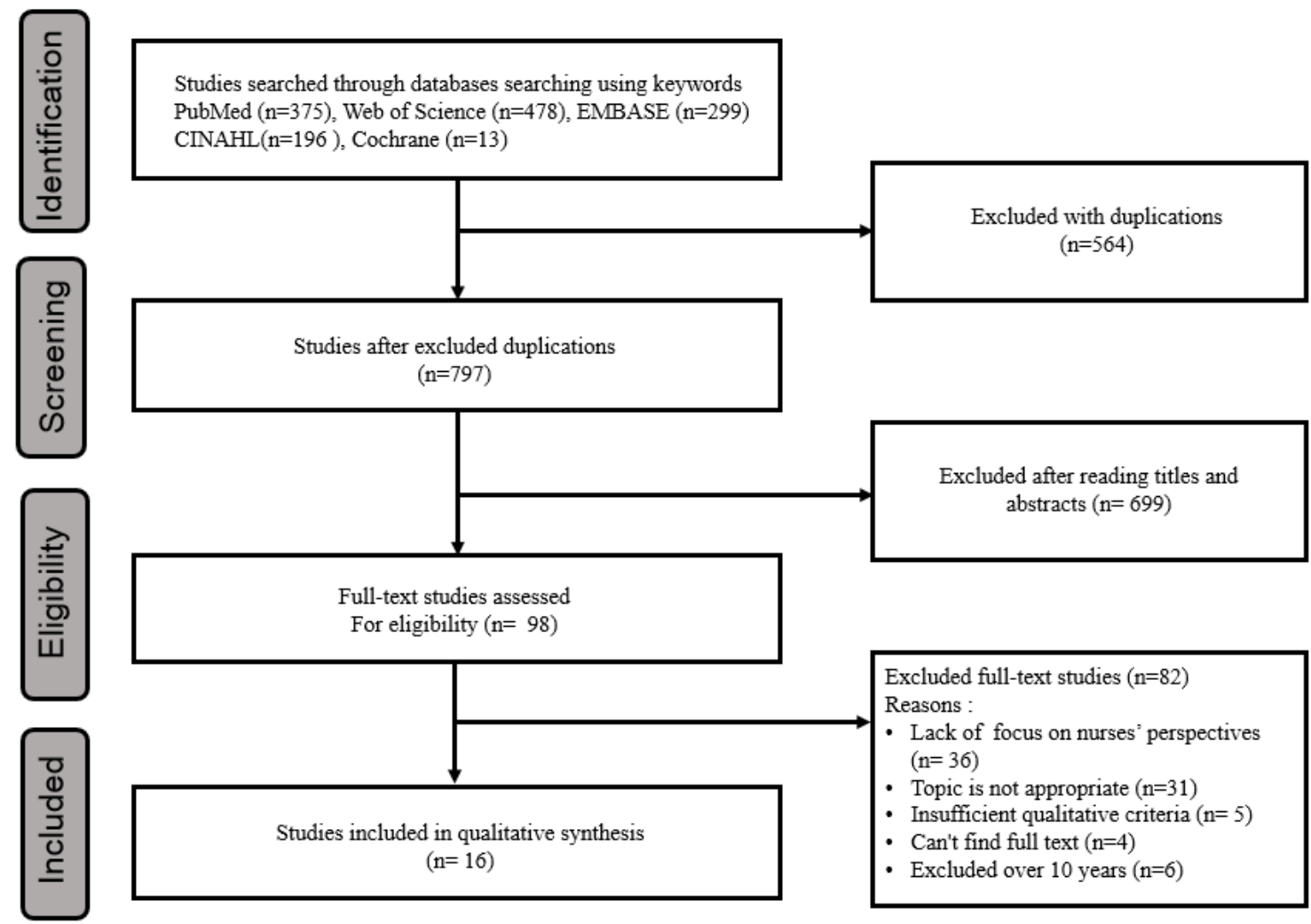

Figure 1

The flow of this study

\section{Supplementary Files}

This is a list of supplementary files associated with this preprint. Click to download.

- ENTREQ0923.docx

- Appendix1.docx 